\title{
Incidence of malnutrition, esophageal stenosis and respiratory complications among children with repaired esophageal atresia
}

Incidência de desnutrição, estenose esofágica e complicações respiratórias entre crianças operadas por atresia esofágica

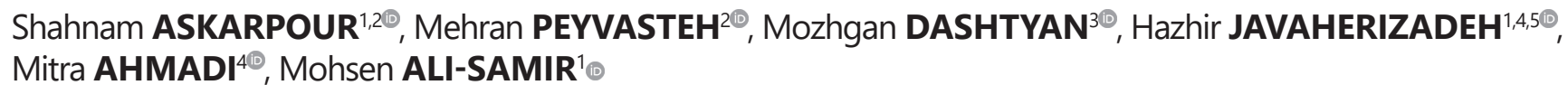

ABSTRACT - Background: Esophageal atresia is congenital anomaly with high mortality. Surgical complications and changes in nutritional status are common problems after surgical correction. Aim: To evaluate nutritional status, esophageal stenosis, and respiratory complications among children who had repaired esophageal atresia. Methods: Children aged $>2$ months old with repaired esophageal atresia were included in the current study. Gender, age, weight, and height were recorded for each case. Height for age and weight for age were calculated for each case. Results: According to weight for length percentile, $41.02 \%$ of the cases were underweight. Esophageal stenosis was seen in $54.76 \%$ of the obtained esophagograms. Conclusion: Underweight was present in 41.02 of the patients according to weight-for-height percentile.

HEADINGS - Esophageal stenosis. Esophagus. Malnutrition

RESUMO - Racional: Atresia de esôfago é anomalia congênita com mortalidade alta. Complicações cirúrgicas e alterações no estado nutricional são problemas comuns após correção cirúrgica. Objetivo: Avaliar o estado nutricional, a estenose esofágica e as complicações respiratórias em crianças que tiveram a reparação de atresia de esôfago. Métodos: Crianças com idade> 2 meses de idade com atresia esofágica reparada foram incluídas no estudo atual. Sexo, idade, peso e altura foram registrados para cada caso. A altura por idade e o peso por idade foram calculados para cada caso. Resultados: De acordo com o peso para o percentil de comprimento, $41,02 \%$ dos casos estavam abaixo do peso. Estenose esofágica foi observada em $54,76 \%$ do esofagograma obtido. Conclusão: O baixo peso esteve presente em 41,02 dos pacientes, de acordo com o percentil peso/estatura. DESCRITORES: Estenose esofágica. Esôfago. Desnutrição

\begin{tabular}{|c|c|}
\hline Percentile & $n=39$ \\
\hline Percentile $<5$ (underweight) & $16(41 / 02 \%)$ \\
\hline $\begin{array}{l}\text { Percentile }>=5 \text { and }<85 \text { (healthy } \\
\text { weight) }\end{array}$ & $14(35 / 90 \%)$ \\
\hline $\begin{array}{l}\text { Percentile }>=85 \text { and }<95 \text { (at risk of } \\
\text { overweight) }\end{array}$ & $5(12 / 83 \%)$ \\
\hline Percentile > =95 (overweight) & $4(10 / 25)$ \\
\hline \multicolumn{2}{|c|}{$\begin{array}{l}\text { Result of weight for height (length) among children } \\
\text { with repaired esophageal atresia }\end{array}$} \\
\hline
\end{tabular}

Central message

Undernutrition is a frequent complication among children with repaired esophageal atresia

How to cite this article: Askarpour S, Peyvasteh M, Dashtyan M, Javaherizadeh H, Ahmadi M, Ali-Samir M. Incidence of malnutrition, esophageal stenosis and respiratory complications among children with repaired esophageal atresia. ABCD Arq Bras Cir Dig. 2020;33(1):e1486. DOI: /10.1590/0102-672020190001e1486

Financial source: Este estudo foi apoiado pelo Technology and Research Development Department of Ahvaz, Jundishapur University of Medical Sciences.

Conflict of interest: none

Received for publication: 15/01/2019

Accepted for publication: 23/05/2019 
E sophageal atresia is a congenital anomaly with estimate prevalence about $1 / 2500-3000$ live births ${ }^{1}$. Mortality on it has decreased from $75 \%$ to $58 \%$ in our setting ${ }^{2}$. So, complication of repaired esophageal atresia and nutritional status of the living child is the most important problem in our hospital.

There are few published researches with the focus on nutritional status among the children with repaired esophageal atresia. The aim of this study was to evaluate malnutrition rate among children with repaired esophageal atresia.

\section{METHODS}

This study was cross sectional and retrospective. It was approved by the institutional Ethics Committee under number IR.AJUMS.REC.1396.57

Hospital charts of the Department of Pediatric Surgery of Imam Khomeini Hospital and outpatient clinic of Abuzar children's hospital of children aged $>2$ months old with repaired esophageal atresia were reviewed. Gender, age, weight, and height were recorded for each case. Height and weight for age were calculated for each case. Percentile of weight for height for boys and girls were calculated (Table 1). For children under three years recumbent position was used for length measurement. Infant weight for age and child weight for age were also calculated for each case.

TABLE 1 - Classification of malnutrition according to weight for height percentile

\begin{tabular}{|c|c|}
\hline Percentile $<5$ & Underweight \\
\hline Percentile $>=5$ and $<85$ & Healthy weight \\
\hline Percentile $>=85$ and $<95$ & At risk of overweight \\
\hline Percentile $>=95$ & Overweight \\
\hline
\end{tabular}

\section{RESULTS}

Of 43 children, 25 were male and 18 female. In 39, recorded mean birth body weight was $2914 \mathrm{~g}(1800-4500)$. According to weight for length percentile, $41.02 \%$ of our cases were underweight (Table 2).

TABLE 2 - Result of weight for height (length) among children with repaired esophageal atresia

\begin{tabular}{|l|c|}
\multicolumn{1}{c|}{ Percentile } & $\mathrm{n}=39$ \\
\hline Percentile $<5$ (underweight) & $16(41 / 02 \%)$ \\
\hline Percentile $>=5$ and $<85$ (healthy weight) & $14(35 / 90 \%)$ \\
\hline Percentile $>=85$ and $<95$ (at risk of overweight) & $5(12 / 83 \%)$ \\
\hline Percentile $>=95$ (overweight) & $4(10 / 25)$
\end{tabular}

Among 41 records about respiratory problem, 14 (34.14\%) children had persistent problem. Among 42 recorded data about contrast esophagograms, 23 children had esophageal stenosis; seven normal esophagus. Contrast esophagogram was not done for 12 due to esophageal stenosis. As a result esophageal stenosis was seen in $54.76 \%$ in esophagograms.
Male was slightly more affected than female with esophageal atresia ${ }^{3-5}$, which is similar to the current study. Our results showed, according to weight for length percentile, undernutrition present among $41.02 \%$ of children with repaired esophageal atresia. In another study from China on 10 patients with esophageal atresia, mild malnutrition was seen in five and severe in one ${ }^{6}$. Undernutrition in our study was slightly lower than that study? This high rate of undernutrition may be due to the high frequency of undernutrition in our country 7,8 .

Respiratory complications which was seen in $34.14 \%$ of the cases are multifactorial and may be due anastomotic leaks ${ }^{9,10}$, recurrence of fistula, and anastomotic stricture. Tracheomalacia was seen in $37.5 \%$ to $75 \%$ of the children who underwent surgery of esophageal atresia ${ }^{11,12}$. Another reason for high rate of respiratory problems may be due to gastroesophageal reflux disease ${ }^{13}$. Esophageal stenosis following repair of esophageal atresia and/ or trachea-esophageal fistula was seen in $54.76 \%$ of the obtained contrast esophagogram.

\section{CONCLUSION}

In repaired esophageal atresia malnutrition was seen in $41.02 \%$, esophageal stenosis in $54.7 \%$ and respiratory problems in $34.14 \%$ of the cases.

\section{REFERENCES}

1. Spitz L. Oesophageal atresia. Orphanet J Rare Dis 2007;2:24.

2. PeyvastehM,AskarpourS,JavaherizadehH,etal.Evaluationofepidemiologic indices of neonate's diseases in the Pediatric Surgery Ward of the Ahvaz Jundishapur University hospitals during the period 1993-1996 and 20022005. Ann Pediatr Surg 2011;7:7-9.

3. Parolini F, Morandi A, Macchini F, et al. Esophageal atresia with proximal tracheoesophagealfistula:amissed diagnosis.JPediatrSurg2013;48:E13-7.

4. Sfeir R, Michaud L, Salleron J, et al. Epidemiology of esophageal atresia. Dis Esophagus 2013;26:354-5.

5. Pini Prato A, Carlucci M, Bagolan $P$, et al. A cross-sectional nationwide survey on esophageal atresia and tracheoesophageal fistula. J Pediatr Surg 2015;50:1441-56.

6. GuanXS, YuJK,ZhongW, etal.[Treatmentstrategyand prognosisanalysis in children with type I esophageal atresia]. Zhonghua Wei Chang Wai Ke Za Zhi 2013;16:860-3.

7. Dehghani SM, Javaherizadeh $\mathrm{H}$, Heidary $M$, et al. Stunting, wasting, and mid upper arm circumference status among children admitted to Nemazee Teaching Hospital. Nutr Hosp 2018:35:33-7.

8. Jafari S, Fouladgar M, Naeeni MM, et al. Body Mass Index, Weight-forage, and Stature-for-age Indices in Iranian School Children in Relation to Weight and Growth Disorders: A Population-based Survey. Int J Prev Med 2014;5:S133-8

9. Chittmittrapap S, Spitz L, Kiely EM, et al. Anastomotic leakage following surgery for esophageal atresia. J Pediatr Surg 1992;27:29-32.

10. Askarpour S, Peyvasteh M, Javaherizadeh $\mathrm{H}$, et al. Evaluation of risk factors affecting anastomotic leakage after repair of esophageal atresia. Arq Bras Cir Dig 2015;28:161-2.

11. CardenKA,BoisellePM,WaltzDA,etal.Tracheomalaciaandtracheobronchomalacia in children and adults: an in-depth review. Chest 2005;127:984-1005.

12. Hseu A, Recko T, Jennings R, et al. Upper Airway Anomalies in Congenital Tracheoesophageal Fistula and Esophageal Atresia Patients. Ann Otol Rhinol Laryngol 2015;124:808-13.

13. Hysinger EB, Friedman NL, Padula MA, et al. Tracheobronchomalacia Is Associated with Increased Morbidity in Bronchopulmonary Dysplasia. Ann Am Thorac Soc 2017 